\title{
Safety Evaluation of Chocolate Brown Dye in Swiss albino Mice
}

Shamme Akter Neshe, Sayema Arefin, Md. Saddam Hussain, Abhijit Das, Palash Karmakar ${ }^{*}$, Mohammad Salim Hossain

Department of Pharmacy, Noakhali Science and Technology University, Noakhali-3814, Bangladesh

*Corresponding author: Palash Karmakar, Assistant Professor, Department of Pharmacy, Noakhali Science and Technology University, Noakhali-3814, Bangladesh, Tel: +8801717036968; E-mail: pk@nstu.edu.bd

Received date: June 25, 2016; Accepted date: August 2, 2016; Published date: August 9, 2016

Copyright: @ 2016 Neshe SA, et al. This is an open-access article distributed under the terms of the Creative Commons Attribution License, which permits unrestricted use, distribution, and reproduction in any medium, provided the original author and source are credited.

\section{Abstract}

Objective: Chocolate Brown is a brown synthetic diazo dye which is mainly used in chocolate cakes and also in other food products. The present study was designed to evaluate toxic effects of chocolate brown dye considering the biochemical and pathological parameters of Swiss albino mice.

Methods: The experimental animals were subdivided into 3 groups such as control, group 1 (received chocolate brown dye at a dose of $200 \mathrm{mg} / \mathrm{kg}$ body weight) and group 2 (received chocolate brown dye at a dose of $400 \mathrm{mg} / \mathrm{kg}$ body weight) containing 5 mice in each of the groups. Different group of mice were fed with normal diet for 25 days and their body weight was taken every day. At $26^{\text {th }}$ day their blood serum and some organ was collected for conducting biochemical and pathological analysis.

Results: During this study a remarkable increase in body weight was noticed in case of group 2 when compared to the control group. But surprisingly group 1 showed less increase in body weight than control group. This study showed that the weight of liver, heart and kidney was increased in case of group 2. While group 1 showed increased in heart weight but its kidney and liver weight was actually lower in comparison to the control group. Furthermore we have also found a significant raise in blood bilirubin level when dose increased from $200 \mathrm{mg} / \mathrm{kg}$ to $400 \mathrm{mg} / \mathrm{kg}$. All the tests showed that chocolate brown dye is more poisonous at higher dose compared to lower one.

Conclusion: Considering the inferential data on the physiological and biochemical parameters of mice the study recommends the withdrawal of the chocolate brown dye from the local market. People should be more concern about the hazardous effects of chocolate brown dye.

Keywords: Chocolate brown; Food products; Physiological; Biochemical; Cholesterol; Triglyceride; Swiss albino

\section{Introduction}

From the organoleptic point of view, the visual aspect of a product is a vital factor for its choice by the consumer which is mostly influenced by the proper use of a color [1]. Color additives have a long tradition of being used as a part of human culture [2] to provide attractive appearance and also to hide poor quality of spoiled food products [3]. Color additives are substances that deliver color when mixed up with food or drink and are available in many different forms comprising of liquids, powders, gels, and pastes. Due to its high tinctorial power, easy availability and cost effectiveness, it is used not only in commercial food production and domestic cooking but also in pharmaceuticals, cosmetics, medical devices and home craft projects $[2,4]$.

Although these additives may come from both natural and synthetic origin, however $95 \%$ of those used now-a-days are synthetic because they are produced easily, cheaper and provide better coloration [3]. However, the Act of Food Adulteration of 1954 (PFAA, 1954) permitted eight synthetic colors namely-indigo, carmoisine, erythrosine, brilliant blue, tartrazine, fast green, sunset yellow and ponceau $4 \mathrm{R}$ to be added in the food items. These dyes are widely encountered in a variety of eatables from both urban and rural markets and are used in the form of blends of one or more dyes. One such commonly used blend is Chocolate Brown which is a synthetic bis-azo dye composed of tartrazine, carmoisine and brilliant blue FCF. It is a brown-colored, water soluble dye which is widely used in soft drinks, candies, ice-creams and beverages [5]. It has the following chemical structure illustrated in Figure 1.

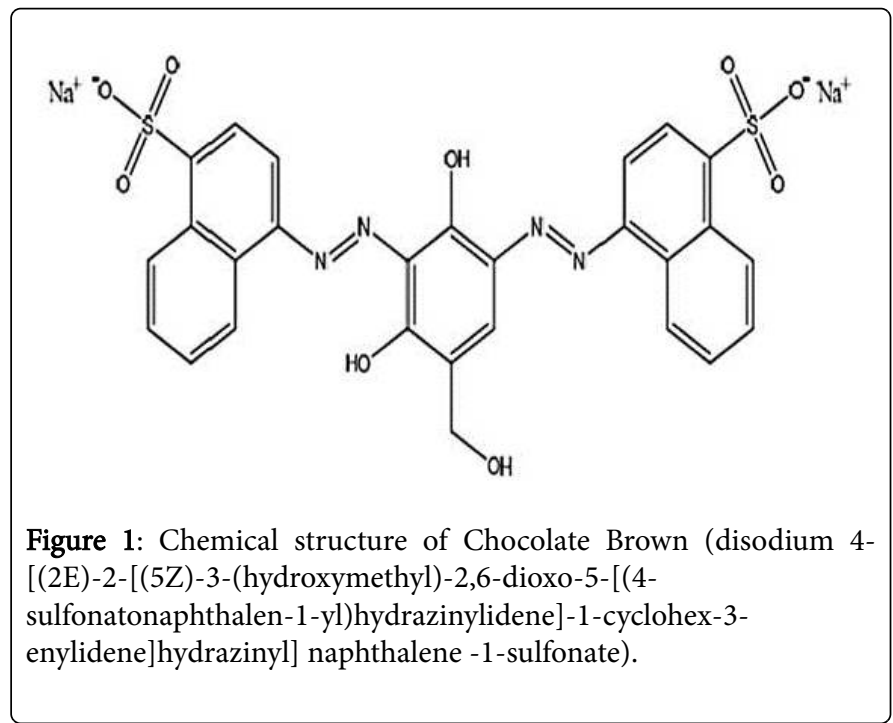

The Acceptable Daily Intake (ADI) for humans is $0-1.5 \mathrm{mg} / \mathrm{kg}$ body weight. However, chocolate brown has been implicated as the synthetic 
coloring agent that is most often responsible for liver and kidney damage as detected by comet assay [6]. Some research reports demonstrated that this chocolate brown dye also responsible for the decrease of body weight, serum and HDL cholesterol level and increase of liver enzyme tested in animal models [7,8]. This chocolate brown dye is frequently used in different food products almost everywhere in Bangladesh although it has been banned by many developed countries of Europe and America. Therefore, the present study was an attempt to investigate the toxicological effect of chocolate brown dye on Swiss albino mice.

\section{Materials and Methods}

\section{Chemicals}

For this research work chocolate brown (Chocolate Brown HT, Food Brown 3, C.I. 20285, E155) chocolate brown dye was purchased from local market.

\section{Animals and housing}

Male and female Swiss albino mice weighing between 25-30 g were used for the study. Mice were collected from Jahangirnagar University, Bangladesh and were housed in a controlled room with a $12 \mathrm{~h}$ lightdark cycle and temperature and humidity of $25 \pm 2^{\circ} \mathrm{C}$ and $55 \pm$ $10 \%$ respectively. They were kept in transparent polypropylene cages and were fed with standard laboratory pellet diet and water at libitum. All the mice were allowed to acclimatize for 7 days to the laboratory conditions before conducting the experiment. Ethical approval was taken from the institutional animal ethical committee.

\section{Experimental design}

For the research work the animals were divided into three groups with 5 animals in each group. All the mice were fed normal diet and two groups were administered with chocolate brown dye along with the normal diet for 25 days at two different doses. Here, group 1 and 2 were administered with chocolate brown dye at a dose of 200 and 400 $\mathrm{mg} / \mathrm{kg}$ body weight along with normal diet. The solution of chocolate brown dye was administered orally, per oral (p. o.) route, using an intra-gastric feeding syringe. Group 3 was considered as the control group and was administered with distilled water.

The animals were observed daily for general conditions. They were weighed once regularly before feeding the chocolate brown dye and a daily record of body weight was fostered. After 25 days the animals were forsaken by cervical prolapse. The body organs and the blood samples were collected to analyze the toxic effect caused by the chocolate brown.

\section{In-vivo toxicity studies}

Body weight analysis: To determine the effect of chronic administration of the chocolate brown (200 and $400 \mathrm{mg} / \mathrm{kg}$ ) on growth rates of the mice, body weight of all of the experimental animals including the controlled group, were carefully observed throughout the 25 days period of chocolate brown dye administration.

Statistical analysis of the initial and final growth of each group of experimental animals was done. Then using the data of the average weight a comparison of the effect of the chocolate brown dye on the growth and weight of the mice was done among the three groups [9].
This following equation was used to calculate the percentage of body weight gain.

\section{The percentage of body weight gain $=$ $\frac{\text { Mean final weight - Mean initial weight }}{\text { Mean initial body weight }} \times 100 \%$}

Biochemical analysis of serum: To collect the serum blood samples were centrifuged at 3,000 rpm for $10 \mathrm{~min}$ using bench top centrifuge (MSE Minor, England). Then collected serum was stored in the refrigerator at $-20^{\circ} \mathrm{C}$ for analysis. The analysis of all the biochemical parameter was accomplished within $24 \mathrm{~h}$ of sample collection. Triglycerides, cholesterol and bilirubin level were determined by Enzymatic method using a UV spectrophotometer (JA.S.CO V-530 UV/vis, Japan) [9].

Pathological examination: After the 25 days period of study, at the day 26 , ketamine $(500 \mathrm{mg} / \mathrm{kg})$ were administered intra-peritoneally to anaesthetize the animal before forsaking. After forsaking the mice, specific organs of interest were separated from the carcasses and preserved in normal saline $(0.9 \% \mathrm{NaCl})$. After collecting the organ (liver, kidney and heart) the weight of each organ of every mouse was measured and the average weights of liver, kidney and heart of each group were compared statistically [9].

Statistical analysis: All the results obtained by in vivo experiment are presented in tables or figures as the mean \pm SEM. The statistical significance of the differences between control and experimental groups was evaluated by Student's ttest using GraphPad Instat 3.06 [1], where $\mathrm{p}<0.05$ was considered as statistically significant.

\section{Results}

\section{Effect on body weight and growth}

Treatment with chocolate brown dye did not significantly affect mortality, clinical signs, food intake and body weight when compared to the control group. Mean body weight curves for Swiss albino mice during the treatment period are shown in Figure 2.

From Figure 2, it is clear that from day 0 to day 10, there was a gradual increase in the body weight of group 2 (mice treated with 400 $\mathrm{mg} / \mathrm{kg}$ b.w. chocolate brown dye) in comparison to the control group, whereas the average weight of control group showed a regular fluctuation. Interestingly after 15 days the average weight of group 1 (mice treated with $200 \mathrm{mg} / \mathrm{kg}$ b.w. chocolate brown dye) began to decrease while the average weight of group 2 increased more than the control group.

\section{Biochemical examination}

Data represented in Table 1 showed an increase in cholesterol, triglyceride and bilirubin level in group administration of chocolate brown dye at the concentration of $400 \mathrm{mg} / \mathrm{kg}$ b.w. But we found cholesterol, triglyceride and bilirubin lowering effect when the animal group was treated with $200 \mathrm{mg} / \mathrm{kg}$ b.w. chocolate brown dye. Except the bilirubin level of group 2 animals there was no significant difference in the level of biochemical parameters among the tested groups. 


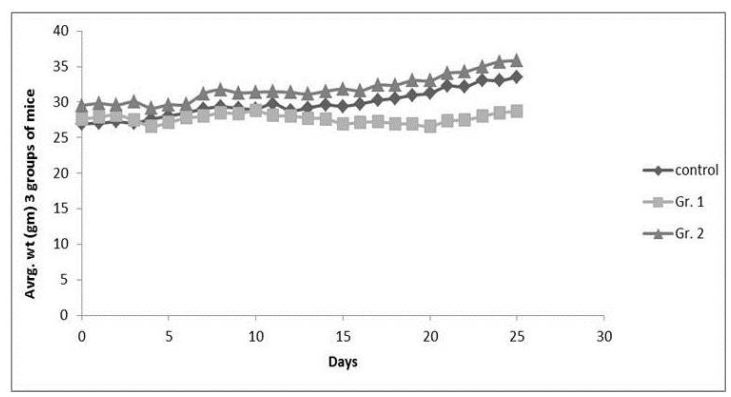

Figure 2: Body weights of Swiss albino mice treated orally with different concentration of chocolate brown dye for 25 days.

\section{Pathological examination}

Pathological examination of the heart, kidney and liver showed that chocolate brown dye insignificantly increased the average weight of heart of the test animals for both group 1 and group $2(0.22 \pm 0.01 \mathrm{~g}$ and $0.23 \pm 0.01 \mathrm{~g}$ respectively). While the average weight of kidney was increased only in case of group 2 animals $(0.389 \pm 0.01) \mathrm{g}$ in comparison to $0.31 \pm 0.04 \mathrm{~g}$ for control group. But the treatment with chocolate brown dye reduced the weight of liver of the test animals in both concentrations ( $1.72 \pm 0.03 \mathrm{~g}$ and $1.84 \pm 0.01 \mathrm{~g}$ respectively) when compared to control group (Figure 3 ).

\begin{tabular}{|l|l|l|l|}
\hline Groups & $\begin{array}{l}\text { Total Cholesterol } \\
\mathbf{m g} / \mathbf{d l}\end{array}$ & $\begin{array}{l}\text { Total Triglycerides } \\
\mathbf{m g} / \mathbf{d l}\end{array}$ & $\begin{array}{l}\text { Total Bilirubin } \\
\mathbf{m g} / \mathbf{d l}\end{array}$ \\
\hline Control & $161.54 \pm 2.29$ & $200.22 \pm 6.75$ & $6.60 \pm 0.28$ \\
\hline Group 1 & $143.85 \pm 12.13$ & $190.04 \pm 6.84$ & $6.12 \pm 0.21$ \\
\hline Group 2 & $215.39 \pm 36.03$ & $247.78 \pm 5.97$ & $8.10 \pm 0.28^{*}$ \\
\hline
\end{tabular}

Values are expressed as mean \pm SEM (Standard error mean); ${ }^{*}$ indicates $\mathrm{P}<0.005$, when compared to control using student's $\mathrm{t}$-test. Control $=$ mice untreated;

Group 1 = mice treated with $200 \mathrm{mg} / \mathrm{kg}$ b.w. chocolate brown and Group $2=$ mice treated with $400 \mathrm{mg} / \mathrm{kg}$ b.w. chocolate brown.

Table 1: Effect of chocolate brown dye on cholesterol, triglycerides and bilirubin levels of the tested animals.

\section{Discussion}

In present of this study, it was noticed that during the administration period ( 25 days) of the chocolate brown dye, there were alterations in body weights of animals. The group of mice fed with the chocolate brown dye showed a marked decrease of body weight in comparison to the control group. A similar type of agreement was reported by Hashem et al., [10] where the increase and decrease in body weight gain was non-significant. Other reports stated that synthetic food colorants cause a significant increase in body weight gain until the fourth month followed by a significant decrease in male and female $[7,11,12]$. Nakaura et al, [13] showed that Pholxine, a food color, causes no significant suppression in the maternal body weight gain and also leads to growth retardation. Meanwhile when a substance leads to the reduction of body weights of tested animals, it is considered that some kind of toxic effect has occurred to them $[14,15]$.
Several researches have also demonstrated similar type of relationship between weight loss and toxicity $[7,8]$.

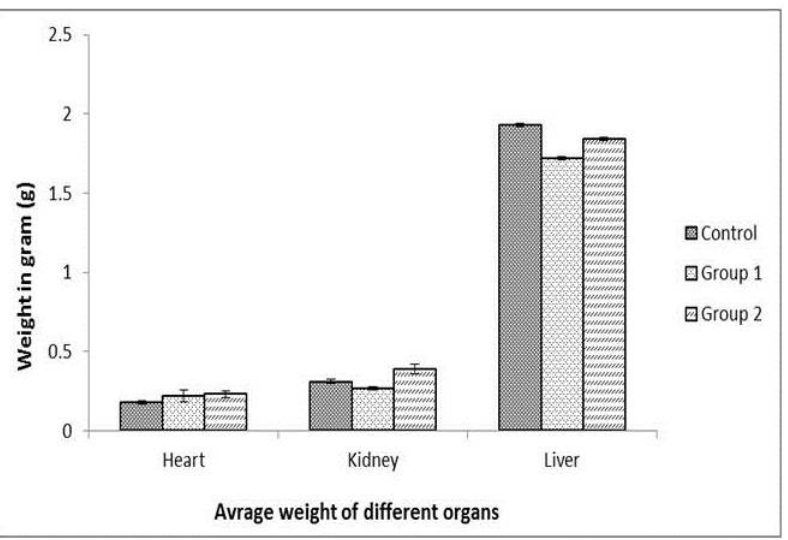

Figure 3: Effect of chocolate brown dye on the average weight of heart, kidney and liver of test animals.

The data of plasma concentration of triglyceride and cholesterol level showed that higher concentration $(400 \mathrm{mg} / \mathrm{kg}$ b.w.) of chocolate brown dye leads to hyperlipidemia in test animals when compared to control group. Whereas the effect of lower dose $(200 \mathrm{mg} / \mathrm{kg}$ b.w.) on triglyceride and cholesterol level was closer to that of the control group. So it can be postulated that higher dose of the chocolate brown dye results in severe toxicity than lower dose. Our study result also correspond previous research reports where AboelZahab et al., [7] reported significant increases in serum total lipids, cholesterol and triglycerides in rats fed with chocolate colours A and B that contained Tartrazine and Carmoisine (sunset yellow, Tartrazine, Carmoisine and brilliant blue) in varying concentrations. El-Malky et al., [16] showed that administration of synthetic colors in overdose leads to significant increase in the lipid profile of rats including total cholesterol, low density lipoproteins (LDL), high density lipoproteins (HDL). Similar types of results were also demonstrated by Soltan and Shehata [2] and Totani et al., [17] which substantiate the authenticity of our research work.

After administration of chocolate brown to the Swiss albino mice a statistically significant $(\mathrm{p}<0.05)$ increase in bilirubin level in serum was noted in group 2 animals in comparison to control group. Serum bilirubin concentration may be elevated due to acute hepatocellur injury, cholestatic injury or biliary obstruction [9]. Thus interpreting our study results it can be said that chocolate brown dye may resulted in obstruction in liver function which increased the serum bilirubin level of the mice. Our study findings were also similar to the data reported by Mehedi et al., [9] who observed a significant elevation in serum bilirubin level with other azo dyes. The increased concentration of bilirubin may also be attributed to the hemolytic destruction of RBC as bilirubin is a waste product which is primarily produced by the normal breakdown of heme, a substance found mainly in the protein hemoglobin in red blood cells (RBCs) [18].

Our result also showed that, the average weight of kidney and heart had been increased insignificantly at the dose of $400 \mathrm{mg} / \mathrm{dl}$ when compared to control group. Furthermore the weight of liver decreased with the treatment of the chocolate brown dye at both of the experimental dose. It was reported that oral ingestion of synthetic dyes 
such Fast Green (12.5 mg/kg/day) and Sunset Yellow ( $5 \mathrm{mg} / \mathrm{kg} /$ day) for 30 days in mice increased the liver and kidney weight [12]. While Maekawa et al. [19] indicated that subchronic tartrazine ingestion in rats decreased the absolute and relative liver in $2 \%$ dose group. As the change of the absolute and relative organs weight is a sign of toxicity [9] thus it is obvious that our experimental chocolate brown dye must have considerable toxicity on respective organ of the test animals.

\section{Conclusion}

The extent to which synthetic chocolate brown azo dye is used in foods and pharmaceuticals suggest that any type of physiological abnormality against using this chocolate brown dye is of clinical importance. The present 25 days study clearly indicates that chocolate brown dye not only leads to changes in biochemical and pathological parameters but also its effect become more risky at higher doses. Therefore, the study suggests that considering all these data of this research work this chocolate brown dye should be banned from the local market and people should have more awareness about the hazardous effects of consuming chocolate brown dye.

\section{Acknowledgement}

The authors are really grateful to all the teachers and staffs of the Department of Pharmacy, Noakhali Science and Technology University for their support and co-operation.

\section{References}

1. Himri I, Bellahcen S, Souna F, Belmekki F, Aziz M, et al. (2011) A 90-day oral toxicity study of tartrazine, a synthetic food dye, in wistar rats. Int J Pharm Pharm Sci 3: 159-169.

2. Soltan SS, Shehata MM (2012) The effects of using color foods of children on immunity properties and liver, kidney on rats. Food Nutr Sci 3: 897-904.

3. Saxena B, Sharma S (2014) Serological changes induced by blend of sunset yellow, Metanil yellow and tartrazine in swiss albino rat, Rattus norvegicus. Toxicol Int 21: 65-68.

4. Hallagan JB, Allen DC, Borzelleca JF (1995) The safety and regulatory status of food, drug and cosmetics colour additives exempt from certification. Food Chem Toxicol 33: 515-528.

5. Sharma A, Goyal RP, Chakravarty G, Sharma S (2005) Haemotoxic Effects of Chocolate Brown, A Commonly Used Blend of Permitted Food Colour on Swiss Albino Mice. Asian J Exp Sci 19: 93-103.
6. Hassan GM (2009) Effect of Some Synthetic Coloring Additives on DNA Damage and Chromosomal Aberration of Rats. Arab J Biotech 13: 13-24.

7. Aboel-Zahab H, el-Khyat Z, Sidhom G, Awadallah R, Abdel-al W, et al. (1997) Physiological effects of some synthetic food colouring additives on rats. Boll Chim Farm 136: 615-627.

8. Helal GE, Zaahkouk AM, Mekkaway AH (2000) Effect of Some Food Colorants (Synthetic and Natural Products) of Young Albino Rats. Egyptian J Hosp Med 1: 103-113.

9. Mehedi N, Mokrane N, Alami O, Ainad-Tabet S, Zaoui C, et al. (2013) A thirteen week ad libitum administration toxicity study of tartrazine in Swiss mice. African J Biotech 12: 4519-4529.

10. Hashem MM, Atta AH, Arbid MS, Nada SA, Asaad GF (2010) Immunological studies on Amaranth, Sunset Yellow and Curcumin as food colouring agents in albino rats. Food Chem Toxicol 48: 1581-1586.

11. Borzelleca JF, Olson JW, Reno FE (1989) Lifetime toxicity/carcinogenicity study of FD \& C Red No. 40 (allura red) in Sprague-Dawley rats. Food Chem Toxicol 27: 701-705.

12. Osman MA, Afifi A, Hussein RM, Kamilia B, Abdel AI, et al. (1995) Long-Term Biochemical and Genotoxicity Studies of Four Synthetic Food and Drug Colorants in Mice. Bulletin of Faculty of Pharmacy: Cairo University 1: 13-21.

13. Nakaura S, Kawashima K, Nagao S, Tanaka S, Takanaka A, et al. (1975) Studies on the teratogenicity of food additives, 4: Effects of food dye red No. 104 (phloxine) on the pre-and postnatal development in rats in relation to fetal distribution. J Food Hygienic Society Japan 16: 34.

14. Hiremath SP, Badami S, Swamy HK, Patil SB, Londonkar RL (1997) Antiandrogenic effect of Striga orobanchioides. J Ethnopharmacol 56: 55-60.

15. Sharma G, Gautam D, Goyal RP (2009) Tartrazine Induced Haematological and Serological Changes in Female Swiss albino Mice, Mus musculus. Pharmacologyonline 3: 774-788.

16. El-Malky WA, Khiralla GM, Salem SA (2014) Nutritional study of some coloring agents on experimental rats. Int J Nutr Food Sci 3: 538-544.

17. Totani N, Yawata M, Ojiri Y, Fujioka Y (2007) Effects of trace acrylamide intake in Wistar rats. J Oleo Sci 56: 501-506.

18. Al-Shinnawy MS, Elkattan NA (2013) Assessment of the changes in some diagnostic parameters in male albino rats fed on an Azo Dye. Int J Environ Sci Eng 4: 85-90.

19. Maekawa A, Matsuoka C, Onodera H, Tanigawa H, Furuta $K$, et al. (1987) Lack of carcinogenicity of tartrazine (FD \& C Yellow No. 5) in the F344 rat. Food Chem Toxicol 25: 891-896. 